\title{
揚水による不圧帯水層の非定常流れの一解法
}

\section{A Solution of Uunsteady Flow in Unconfined Aquifer \\ by Pumping through Well}

\author{
星田義治*・洪野敬造*・市川 勉* \\ Yoshiharu Hoshida, Keizo Hamano ग] \\ and Tsutomu IchIKawa
}

\begin{abstract}
The unsteady flow by pumping up in unconfined Aquifer is exprssed as in Eq. (1).

$$
\frac{\partial \mathrm{h}}{\partial \mathrm{t}}=\frac{\mathrm{k}}{\beta} \frac{1}{\mathrm{r}}-\frac{\partial}{\partial \mathrm{r}}\left(\mathrm{rh} \frac{\partial \mathrm{h}}{\partial \mathrm{r}}\right)
$$

Where $\mathrm{k}$ : hydraulic conductivity, $\beta$ : effective porocity, $\mathrm{h}:$ the water level at a distance $r$ from the center of pumping well, $t:$ time.

The existing solutions are almost approximative ones because Eq. (1) cannot be solve dexactly. And the radius of well is negrected in these ones.

In this paper, the atthors chage the Eq. (1) into the non-dimensional simultaneous ordinary differential equation, and calculate numerically by means of Runge-Kutta method. In this case. the numerical calculation is done under the condition that the radius of well is finite. The calculated value is described as a diagram (this is called the equidischarge type-curves diagram), and a graphical method which calculate formation constants is proposed (this is called the equi-discharge type-curves method). The equidischarge type-curves method is compared with existing methods and discussed using datas by model tests and field tests. Using this equi-discharge type-curves method, analysis become simple, and more uniform result is obtained in comparison with the resultusing existing methods.

\section{1. 緒 論}

不圧地下水の揚水による非定常状態に対しては，従来，Theis・野満の解，Jacob の解等が主に使 用されている。しかし，基礎式が非線形のため，これらは近似解となっている。この観点から、これ らの近似を行なわずに，基礎式を連立常微分方程式に变形し，これを数值計算した。この計算結果を 線図化し（この線図を等汲み出し線図と呼んでいる），実験データより得られた曲線をこの等汲み出

* 東海大学工学部 
し線図に重ねることによって，帯水層定数を求める一方法（この方法を等汲み出し線法と呼んでい る）を提案し，室内実験および現場揚水試験のデータをもとに，従来の方法と比較検討を行なった。

この数值計算 (非線形解) と線形解である Theis・野满の解と比較すると, 非線形効果が定量的に 把握できる。また，この数值計算では，従来の解が井戸の半径を無視しているのに対し，井戸の半径 を有限としていることから，井戸の中心から任意距離汇拈ける水位の時間的変化を計算することがで きる。そのため，帯水層定数を求める時も，揚水井や観測井のデータを同時に解析することができ， 解析も従来に比べ, 簡単で, 比較的安定した值を得ることがでさる。また, 任意時刻に扣ける影響半 径や任意地点の水位降下を予測することも可能となる。

\section{2. 従来の研究}

1935年, Theis が被圧地下水に㧊ける揚水による非定常状態の解析を行なってから，揚水による非 定常浸透の理論は, 多くの研究者によって発表されてきた。被圧地下水の非定常浸透の基礎式は, 線 形偏微分方程式となり，そのまま基礎式を解くことができる。

一方，不圧地下水の非定常浸透の基礎式は，次式で表わされる。

$$
\frac{\partial \mathrm{h}}{\partial \mathrm{t}}=\frac{\mathrm{k}}{\beta \mathrm{r}} \frac{\partial}{\partial \mathrm{r}}\left(\mathrm{rh} \frac{\partial \mathrm{h}}{\partial \mathrm{r}}\right)
$$

初期条件扣よび境界条件は,

$$
\left.\begin{array}{ccc}
\mathrm{t}=0 & & : \eta=0 \\
\mathrm{t}>0, & \mathrm{r}=\mathrm{r}_{0}: & : \mathrm{Q}_{\mathrm{r} 0}=\mathrm{Q} \quad(=\text { const. }) \\
& \mathrm{r} \rightarrow \infty
\end{array}\right\}
$$

ここで， $\mathrm{Q}$ : 揚水量, $\mathrm{h}$ : 井戸の中心から $\mathrm{r}$ の距離に批ける水位, $\eta$ : 井戸の中心から $\mathrm{r}$ の距離に括け る水位降下, $\mathrm{Q}_{\mathrm{r} 0}$ : 井戸の縁に打流流量, $\mathrm{k}$ : 透水係数, $\beta$ : 有効空吵率, $\mathrm{H}$ : 揚水前の水位 (図 2 -1 参照）。

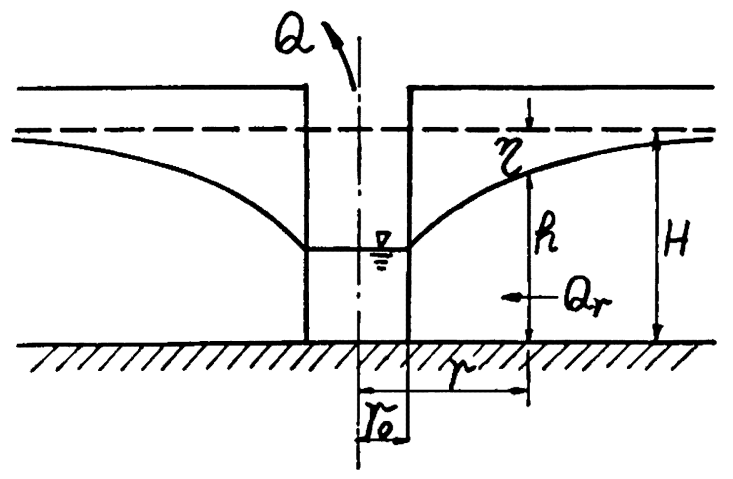

因 2-1 不王帯水層

（2.1）式は，次のような仮定のもとに成り立っている。

1）帯水層は，均質等方であり，無限に広がっている。

2）帯水層下の不透水層の上面は，水平であり，下からの水の補給はない。

3）井戸は，完全貫入井戸であり，井戸ロスはない。

4）地下水の流れは，準一様流の仮定を満足し，Darcy の法則が成立する。

5）井戸に括ける浸み出し量と汲み出し量は等しい。 
（2.1）式を見ればわかるように，不圧地下水の非定常浸透の基礎式は；非線形偏微分方程 式とな り，厳密解を求めることはできない。

1935年，野満らは，この基礎式を水位降下が揚水前の水位に比べ十分小さい（ $\mathrm{h} \fallingdotseq \mathrm{H} ）$ とて,

（2.1）式を解いた。その解は，次式で表わされる。

$$
\eta=\frac{\mathrm{Q}}{4 \pi \mathrm{kH}} \int_{\mathrm{u}}^{\infty} \frac{\mathrm{e}^{-\mathrm{u}} \mathrm{u}}{\mathrm{u}} \mathrm{du}=\frac{\mathrm{Q}}{4 \pi \mathrm{kH}} \mathrm{W}(\mathrm{u})
$$

ここで, $\mathrm{W}(\mathrm{u})$ は井戸関数と呼ばれるものであり, $\mathrm{u}=\beta \mathrm{r}^{2} /(4 \mathrm{kHt})$ である。この解は, Theis・野満 の解と称する。

1946年, Jacobは，井戸関数を級数展開したものを用いて，（2.3）式を次式のように表わし，帯水 層定数算定法を提案している。（この方法を Jacob の直線法と称している。）

$$
\eta=\frac{2.303 \mathrm{Q}}{4 \pi \mathrm{kH}}\left(\log \frac{\mathrm{t}}{\mathrm{r}^{2}}-\log \frac{\beta}{2.25 \mathrm{kH}}\right)
$$

しかし，この近似が，水位降下の大きさによって，ぞの程度結果に影響があるものなのかというこ とについては，はっきりしていなかった。

1965年，岸・三宅・池田は，(2.1）式を摂動法により，野満らの近似を行なわずに解いだ。この解 は, 次式で示される。

$$
\zeta=\frac{\eta}{\mathrm{H}}=\delta \zeta_{1}+\frac{1}{2}\left(\delta \zeta_{1}\right)^{2}+\frac{1}{2}\left(\delta \zeta_{1}\right)^{3}+\cdots \cdots
$$

ここで,

$$
\begin{aligned}
& \zeta_{1}=\int_{\xi}^{\infty} \frac{\mathrm{e}^{-\xi^{2}}}{\xi} \mathrm{d} \xi=\frac{1}{2} \int_{\mathrm{u}}^{\infty} \frac{\mathrm{e}^{-\mathrm{u}}}{\mathrm{u}} \mathrm{du}=\frac{1}{2} \mathrm{~W}(\mathrm{u}) \\
& \mathrm{u}=\xi^{2}=\frac{\beta \mathrm{r}^{2}}{4 \mathrm{kH \textrm {H }}}, \quad \delta=\frac{\mathrm{Q}}{2 \pi \mathrm{kH}^{2}}
\end{aligned}
$$

この解を岸・三宅・池田の解と称する。この解は, 基礎式を理論的に解いた解であるが, 誘導の過 程で近似をしている。また，专用上のことを考慮して，(2.5）式のよらに，第 3 項まで求めている。 理論的に基礎式の解を求めたものでは, 岸らの解が現在のところ最す敩密解に近いものと思われる。 第 4 項以降を著者らが計算したところ，次のようになった。

$$
\zeta=\delta \zeta_{1}+\frac{1}{2}\left(\delta \zeta_{1}\right)^{2}+\frac{1}{2}\left(\delta \zeta_{1}\right)^{3}+\frac{5}{8}\left(\delta \zeta_{1}\right)^{4}+\frac{7}{8}\left(\delta \zeta_{1}\right)^{5}+\cdots \cdots
$$

一方, 近年, コンピュータが急激に発達し, このコンピュータを用いて数值解を求める動きがでて きた。1966年, J.Kriz らは，(2.1）式を変形し，Runge-Kutta 法によって数值計算を行なった。 そして，この結果を線図として表わし，この線図による帯水層定数算定法を提案している。その計算 式は，次式で表わされる。

$$
\frac{\mathrm{d}^{2} \omega}{\mathrm{d} \xi^{2}}+\left(\frac{1}{\xi}+\frac{1}{\sqrt{\omega}}\right) \frac{\mathrm{d} \omega}{\mathrm{d} \xi}=0
$$

この式に即した形の境界条件は,

$$
\left.\begin{array}{l}
\lim _{\xi \rightarrow \infty} \sqrt{\omega}(\xi)=1 \\
\lim _{\xi \rightarrow 0} \xi \frac{\mathrm{d} \omega}{\mathrm{d} \xi}=\frac{\mathrm{Q}}{2 \pi \mathrm{k} \mathrm{H}^{2}}
\end{array}\right\}
$$


ここで, $\xi=\beta \mathrm{r}^{2} /(4 \mathrm{kHt}), \omega=\mathrm{g}^{2}=(\mathrm{h} / \mathrm{H})^{2}$ である。

これらの解は，すべて同じ仮定，条件で解かれている。ただし（2.2）式に示した境界条件で，

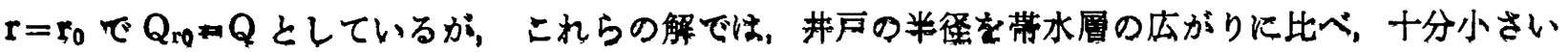
として無視している。（ $\mathrm{r}=0$ で $\mathrm{Q}_{\mathrm{r}}=\mathrm{Q} ）$ したがって，その差は，いかに忠実に基礎式を解くかとい らことになろら。

\section{3. 等汲み出し楾法 (I)}

\section{3-1 基礎式の数值計算}

(2.1) 式を $\mathrm{y}=\mathrm{r}^{2} /(4 \mathrm{CHt})(\mathrm{C}=\mathrm{k} / \beta)$ を使って变数变換し，境界条件を導入すると，次の連立常微 分方程式となる。

$$
\left.\begin{array}{l}
\frac{d z}{d y}=-\frac{z}{g} \\
\frac{d g}{d y}=\frac{z}{g y}
\end{array}\right\}
$$

初期条件および境界条件は，次のようになる。

$$
\begin{array}{ll}
\mathrm{y} \leqq 0 & : \mathrm{g}=1 \\
\mathrm{y}>0, \quad \mathrm{y}=\mathrm{y}_{0}=\frac{\mathrm{r}_{0}{ }^{2}}{4 \mathrm{CHt}} & : \mathrm{z}=\mathrm{z}_{0}=\frac{\mathrm{Q}}{4 \pi \mathrm{kH}^{2}} \\
& : \mathrm{g} \rightarrow \infty=1
\end{array}
$$

（3.1）式を導く仮定は，従来の解と全く同じであるが，従来の解と異なる点は，従来の解が，境界 条件で， $r=0$ で $\mathrm{Q}_{\mathrm{r}}=\mathrm{Q}$ としているのに対し，等汲み出し線（I）では， $r=r_{0}$ で $\mathrm{Q}_{\mathrm{r} 0}=\mathrm{Q}$ (井戸の 半径は有限)としている点である。

（3.1）式は,このままでは解けないので, 数值計算を行なった。この数值計算は, 2 点境界值問題 として取扱い，計算手法は，Runge-Kutta 法を用いた。この計算結果を次のように線図として表わ した。

片対数紙の横軸に $\mathrm{y}$ ，綎軸に $\mathrm{g}(=\mathrm{h} / \mathrm{H})$ をとり， $\mathrm{g}$ と $\mathrm{y}$ の関係を表わした曲線(この曲線を $\mathrm{g}$ 曲 線と呼ぶ）を描く，次に，各 $\mathrm{g}$ 曲線上の $\mathrm{z}$ の等しい点を結び， $\mathrm{z}$ を $z_{0}$ とする(この曲線を等汲み出

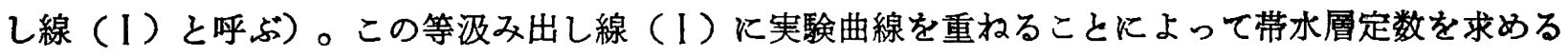
ことができる。 $z_{0}$ は無次元の汲み出し量を表わし，この汲み出し量が一定である位置は揚水井である ので, 等汲み出し線 (I) は, 揚水井に打ける水位変化を表わするのである。この等汲み出し線 (I) を図 3-1 亿示す。

2.で述べた従来の解す等汲み出し線（I）と同様な曲線に表わすことができる。

Theis・野満の解は，（2.3）式より，

$$
\mathbf{g}=\frac{\mathbf{h}}{\mathrm{H}}=1-\frac{\eta}{\mathrm{H}}=1-\frac{\mathrm{Q}}{4 \pi \mathrm{kH}^{2}} \mathrm{~W}(\mathrm{u})=1-\mathrm{Z}_{0} \mathrm{~W}(\mathrm{u})
$$

これを等汲み出し線（I）と比較したのは，図 3-2である。また，岸・三宅・池田の解は，

$$
\mathrm{g}=1-\mathrm{Z}_{0} \mathrm{~W}(\mathrm{u})-\frac{1}{2}\left(\mathrm{Z}_{0} \mathrm{~W}(\mathrm{u})\right)^{2}-\frac{1}{2}\left(\mathrm{Z}_{0} \mathrm{~W}(\mathrm{u})\right)^{3}
$$

となり，同様炕此較することができる。図 3-2を見ると，水位降下率（水位降下／初期水位）が約 10\%付近まで一致している。また（3.4）式より，岸・三宅・池田の解と等汲み出し線（I）を比較 


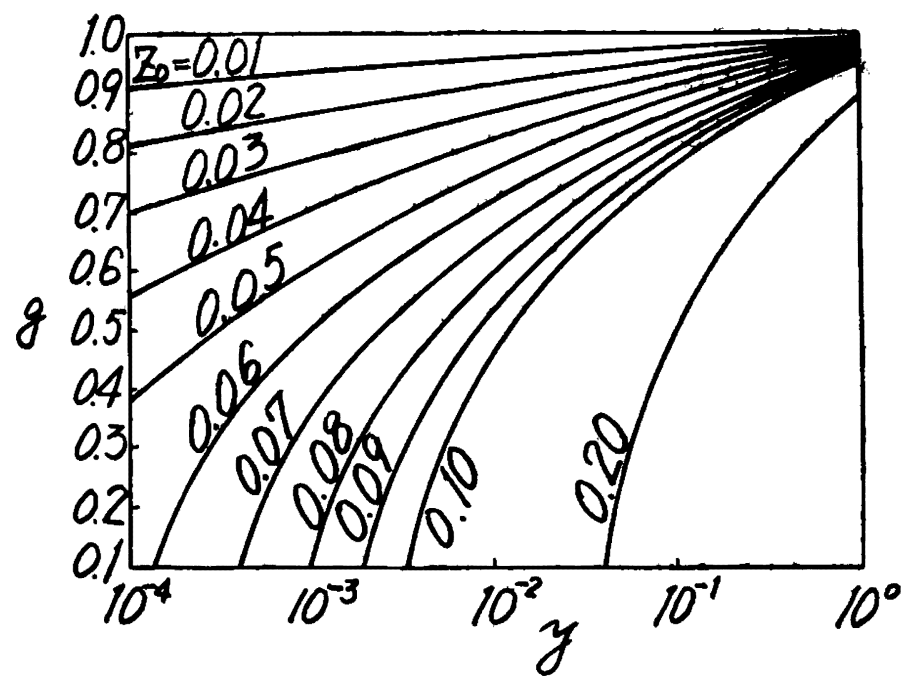

図 3-1 等汲み出し線 (I)

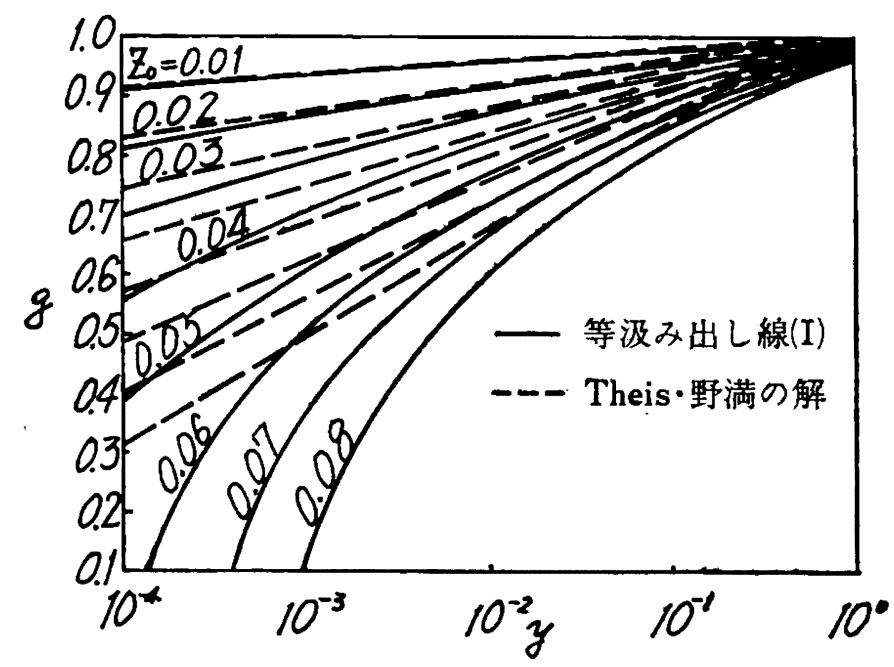

図 3-2 等汲み出し線 (I) と Theis・野満の解の比較

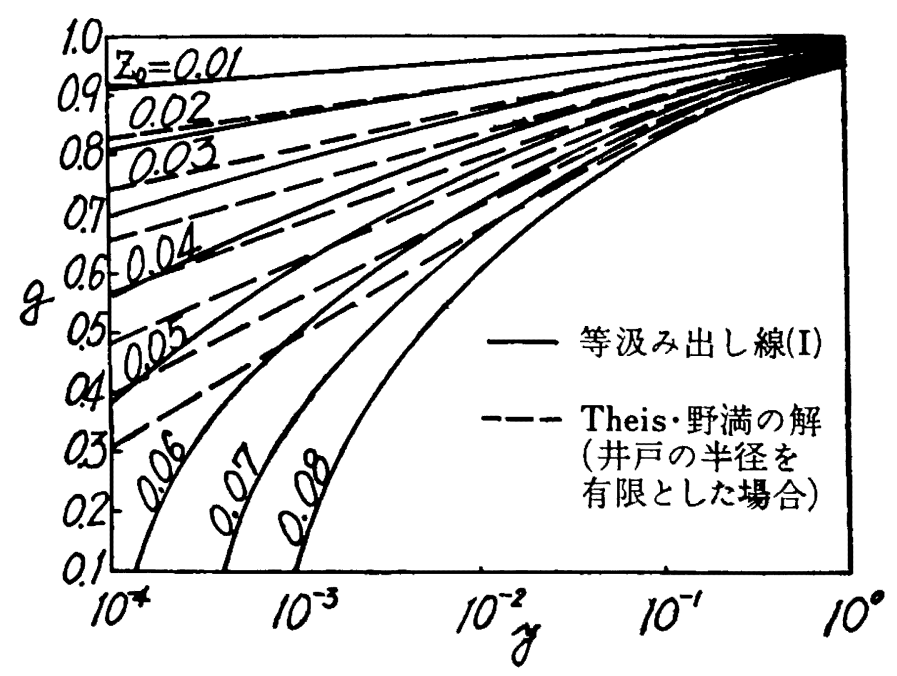

困3-3 等汲み出し線（I）とTheis・野満の解（井戸の半径を有限とした场合）の此交 
すると，水位降下率が約 $40 \%$ まで一致する。次に，Kriz らの解は，すでに線図化されているので比 較すると，等汲み出し線（１）とほぼ一致した。これらの比較で共通していることは，y の值の大き いところで, 従来の解と等汲み出し線（I）と一致しないことである。（図 $3-2$ 参照）これは, 従 来の解の境界条件が, 井戸の半径を無視しているのに対し，等汲み出し線（１）では, 井戸の半径を 有限としたためである。

Theis・野満の解, 岸らの解について, 井戸の半径を有限として解いてみると, 次のようになる。

$$
\begin{aligned}
& \mathrm{g}=1-\mathrm{Z}_{0} \mathrm{~W}(\mathrm{y}) \mathrm{e}^{\mathrm{y}_{0}} \\
& \mathrm{~g}=1-\mathrm{z}_{0} \mathrm{~W}(\mathrm{y}) \mathrm{e}^{\mathrm{y}_{0}}-\frac{1}{2}\left(\mathrm{z}_{0} \mathrm{~W}(\mathrm{y}) \mathrm{e}^{\mathrm{y}_{0}}\right)^{2}-\frac{1}{2}\left(\mathrm{z}_{0} \mathrm{~W}(\mathrm{y}) \mathrm{e}^{\mathrm{y}_{0}}\right)^{3}
\end{aligned}
$$

ここで, $\mathrm{y}_{0}=\mathrm{r}^{2} /(4 \mathrm{CHt})=\left(\mathrm{U}_{0}\right)$ である。

（3.5）式と等汲み出し線（I）を比較したのが図 3-3である。図 3-2で見られたyの值の大き いところでの不一致は，図 3-3では見られない。岸らの解についても同様になる。

\section{$3-2$ 等汲み出し線法 (I)}

この等汲み出し線（I）を使用した帯水層定数算定法（等汲み出し線法（I）と呼ぶ）は, 次のよ らな手順で行なら。

1）実測值より, $\mathrm{y}=\mathrm{r}^{2} /(4 \mathrm{Ht}), \mathrm{g}=\mathrm{h} / \mathrm{H}$ を計算し, 片対数紙の横軸に $\mathrm{y}^{\prime}$, 轱軸に $\mathrm{g}$ をとり, $\mathrm{y}^{\prime} に$ 対する $\mathrm{g}$ の值をプロットする。

2）実測値より得た 1)の曲線を等汲み出し線（Ｉ）に重ね， g の值を一致させながら実験曲線と最 も良く合致する等汲み出し線 (I )を見つける。

3）合致した状態で， $Z_{0}$ の值と $\mathrm{y}^{\prime}$ に対応する $\mathrm{y}$ の值を読さ。

4）これらの結果より，次のようにして透水係数 $(\mathrm{k})$ と有効空隙率 $(\beta)$ を求める。 $z_{0}$ の值より

$$
\mathrm{k}=\mathrm{Q} /\left(4 \pi \mathrm{Z}_{0} \mathrm{H}^{2}\right)
$$

$\mathrm{y} お よ ひ ゙ \mathrm{y}^{\prime}$ の值より,

$$
\frac{\mathrm{y}^{\prime}}{\mathrm{y}}=\frac{\mathrm{r}^{2}}{4 \mathrm{Ht}} / \frac{\mathrm{r}^{2}}{4 \mathrm{CHt}}=\mathrm{C}=\frac{\mathrm{k}}{\beta}
$$

\section{4. 等汲み出し線法 (II)}

（2.1）式を $\tau=\mathrm{kHt} /\left(\beta \mathrm{r}_{0}{ }^{2}\right), \mathrm{y}=\mathrm{x} / \sqrt{\tau}, \mathrm{x}=\mathrm{r} / \mathrm{r}_{0}, \mathrm{y}_{0}=1 / \sqrt{\tau}, \xi=\mathrm{y} / \mathrm{y}_{0}$ を使って変形し, 境界条 件を導入すると，次の連立常微分方程式となる。

$$
\left.\begin{array}{rl}
\frac{\mathrm{dz}}{\mathrm{d} \xi} & =\frac{\mathrm{z}}{\xi \mathrm{g}} \\
\frac{\mathrm{dz}}{\mathrm{d} \xi} & =-\frac{\mathrm{y}_{0}^{2} \xi \mathrm{z}}{2 \mathrm{~g}}
\end{array}\right\}
$$

（4.1）式に対応する境界条件は,

$$
\left.\begin{array}{l}
\xi=1:\left.\xi g \frac{\mathrm{dg}}{\mathrm{d} \xi}\right|_{\xi=1}=z_{0}=\frac{\mathrm{Q}}{2 \pi \mathrm{kH} H^{2}} \\
\xi \rightarrow \infty: \quad g=1
\end{array}\right\}
$$

（4.1）式を導く仮定は，従来と全く同じであり，(4.2）式の境界条件も等汲み出し線( I )の場合と 同じである。.(4.1) 式を.Runge-Kutta 法によって数值計算すると，各 $z_{0}, y_{0}$.の值に対して， $x$, 
g, $z$ の一連の値が計算される。この計算は，東海大学電子計算機システム，UNIVAC 1108を用いて 行なった。また，3.で示した等汲み出し線（Ｉ）の数值計算は，東海大学電子計算機システム，FACO M 45/55 OS-2 を用いて行なった。この計算結果より，ある $z_{0} に$ 対して, パラメータ $\mathrm{y}_{0}$ の各値に ついて， $\mathrm{x}-\mathrm{g}$ 曲線を描くと水位の時間的空間的変化を表わすことができる。これを図 4 - 1 に実線

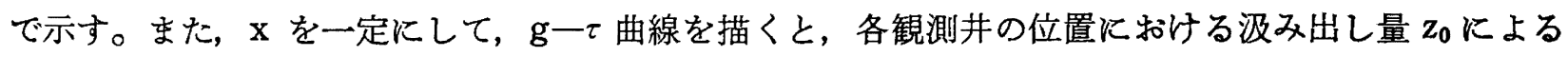
水位の時間的変化を表わすことができる。（これらの線困を等汲み出し線(II)と呼ぶ。）これらの図 を用いれば，帯水層定数を求めることができ，また，影響半径も井戸の中心から任意距離に拈ける水 位変化も予测可能となる。

従来の解も等汲み出し線 (II)と同様に，水位の時間的空間的変化を描くことができる。

・ Theis 野捛の解は, $\mathrm{y}=\mathrm{y}_{0} \mathrm{x}^{2} よ り$,

$$
\mathrm{g}=1-\mathrm{Z}_{0} \mathrm{~W}\left(\mathrm{y}_{0} \mathrm{x}^{2}\right) \mathrm{e}^{\mathrm{y}_{0}}
$$

一方, 岸らの解は, 次のようになる。

$$
\mathrm{g}=1-\mathrm{Z}_{0} \mathrm{~W}\left(\mathrm{y}_{0} \mathrm{x}^{2}\right) \mathrm{e}^{\mathrm{y}_{0}}-\frac{1}{2}\left(\mathrm{z}_{0} \mathrm{~W}\left(\mathrm{y}_{0} \mathrm{x}^{2}\right) \mathrm{e}^{\mathrm{y}_{0}}\right) \frac{2}{2}\left(\mathrm{z}_{0} \mathrm{~W}\left(\mathrm{y}_{0} \mathrm{x}^{2}\right) \mathrm{e}^{\mathrm{y}_{0}}\right)^{3}
$$

図 4-1には, (4.3) 式で計算した Theis・野満の解と，等汲み出し線(II)とを比較したものであ る。岸らの解も (4.4) 式より同様に比較でさ，これらは，等汲み出し線（I）と比較した場合と同様 な結果となる。

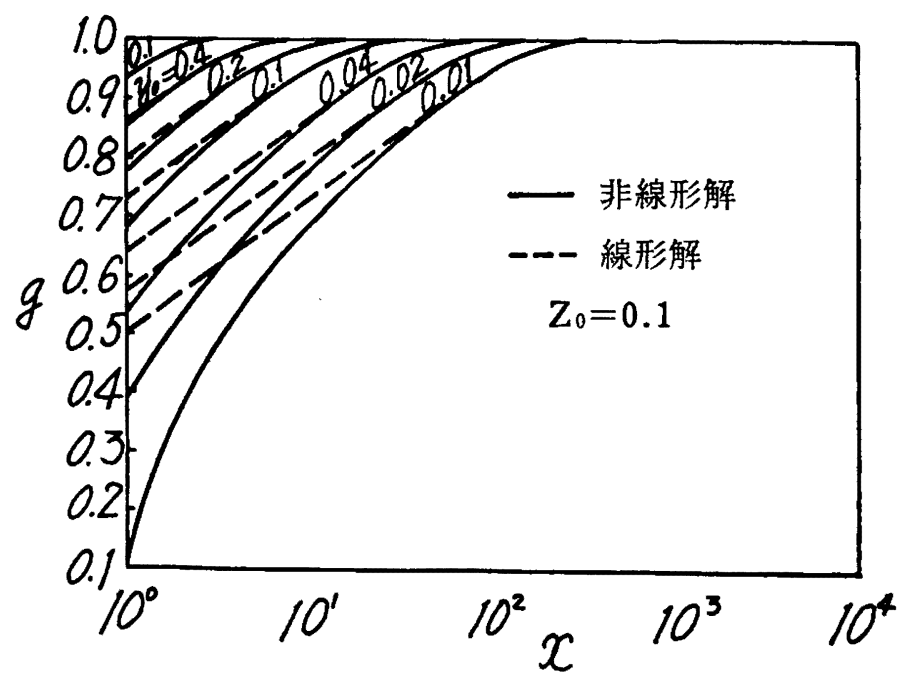

図 4-1 水位の時間的空間的変化図

\section{$4-2$ 等汲み出し線法(II)}

3.で説明した等汲み出し線法（Ｉ）と同様に実験曲線を等汲み出し線（【I）に重ねることによって、帯 水層定数を求めることができる。その式は，次のようになる。

$z_{0}$ の值より,

$$
\mathrm{k}=\mathrm{Q} /\left(2 \pi \mathrm{Z}_{0} \mathrm{H}^{2}\right)
$$

$\tau$ (等汲み出し線 (II)) と $\tau^{\prime}$ (実験曲線) より

$$
\frac{\tau}{\tau^{\prime}}=\frac{\mathrm{kHt}}{\beta \mathrm{r}_{0}^{2}} / \frac{\mathrm{Ht}}{\mathrm{r}_{0}^{2}}=\frac{\mathrm{k}}{\beta}
$$


等汲み出し線法 (II) の場合，等汲み出し線法（Ｉ）や従来の方法と異なり，各観測井のデータを同時 に解析できるので，より安定した帯水層定数を算定でさるものと思われる。

\section{5. 室内実験}

\section{$5-1$ 実験装置および方法}

実験は，円筒形実験装置と円形を1/24にした扇形実験装置を用いて行なった。円筒形実験装置は， 初期水位 $125.2 \mathrm{~cm}$ ，半径 $100 \mathrm{~cm}$ で，中央に直径 $10.53 \mathrm{~cm}$ の揚水井があり，この井戸からサイフォン によって揚水を行なら。井戸の中心から $90 \mathrm{~cm}$ の位置で水位一定とし, 各観測井には, 砂層中に径 2.3 cm のストレーナのついたビニールパイプを立てたものを用い, これらの水位は, 実験装置下部より 逆サイフォンでマノメータへ導き，その水位変化を抵抗線式の記録装置によって自動記録させた。

扇形実験装置は，揚水井の半径 $10 \mathrm{~cm}$ ，揚水井の中心から $2 \mathrm{~m}$ の距離で水位一定とし，揚水は揚水 井よりサイフォンにて行ない, 流量は, 流量計を通すことによって一定化した。各観測井の水位変化 は, 円筒形の場合々同様な方法で測定した。実験に使用した砂は, 比重 2.62 , 平均粒径 $0.8 \mathrm{~mm}$, 均 等俰数 1.96 の砂 (赤砂と呼ぶ), 豊浦産標準砂, 比重 2.60 , 平均粒径 $0.64 \mathrm{~mm}$, 均等係数 1.49 の砂 （白砂と呼ぶ）の 3 種である。ただし，円筒形の実験では，赤砂のみで実験を行なった。

\section{$5-2$ 結果および考察}

解析は, 標準曲線法, Jacob の直線法, Thiem の定常解, 等汲み出し線法（I ），（II）の各方法で 行なった。

Thiem の定常解を除く他の 4 つの方法は, 全て図式解法である。図式解法の場合, 実験曲線の解 析位置によって, 結果が大きく異なる。特に，等汲み出し線法（II）を除く他のつの方法は，曲線が 1 本であるので, 曲線上のいたるところで解析可能である。等汲み出し線法（I）で解析する場合, 実験 曲線は,3つの折れ線に近似できる。そこで，この 3 つの勾配のうち，中央の勾配を使用した。標準 曲線法や Jacob の直線法についても, 同じ位置を使用した。等汲み出し線法 (I ) と等汲み出し線法 （II）の解析例を四 5-1, 図 5-2 亿示す。また, これらの解析結果の一例を図 5-3, 図 $5-4$ 亿 示す。四 $5-3$ は, 透水係数と井戸の中心からの距離, 図 $5-4$ は, 透水係数と水位降下率で結果を

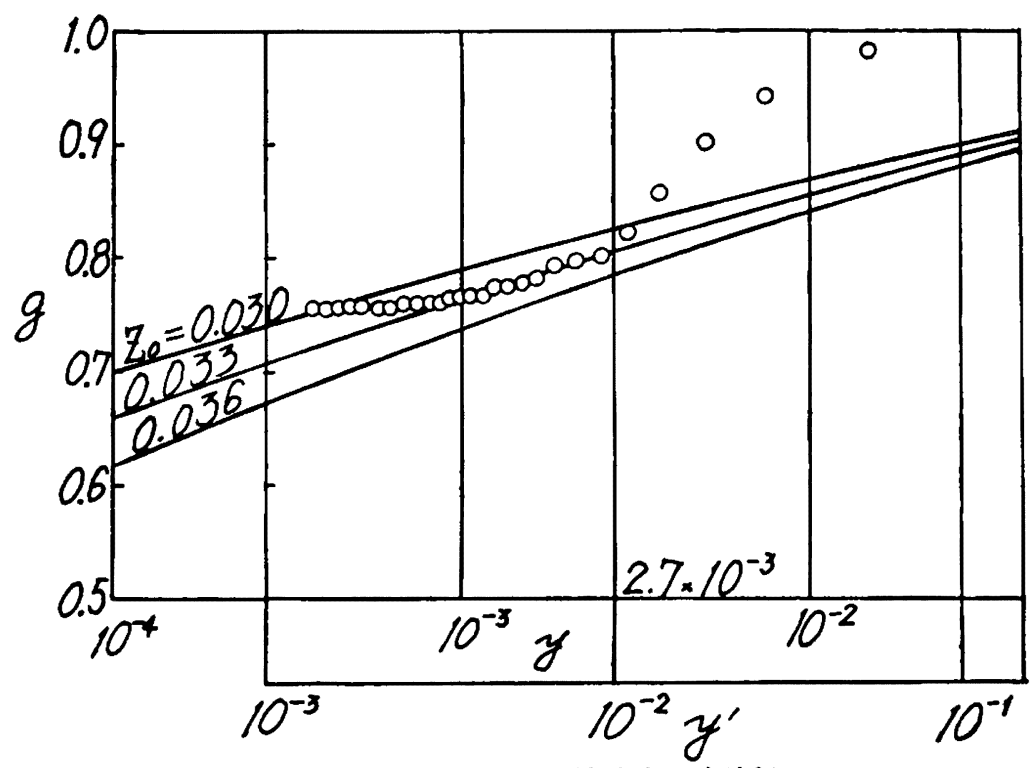

因 5-1 等汲み出し線法( I ) 解析例 


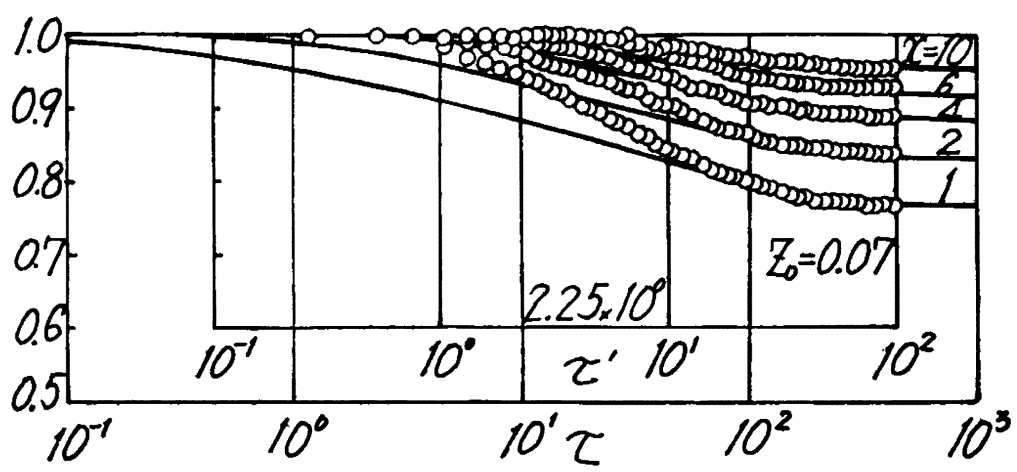

図 5-2 等汲及出し線法(II)解析例

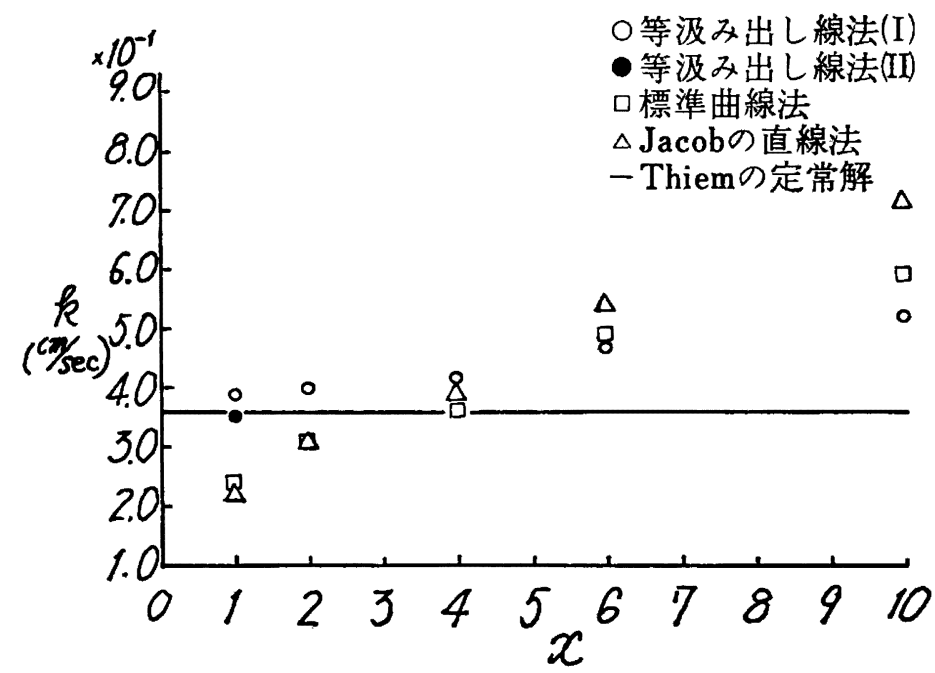

図 5-3 各解析法による解析結果 (室内実験)

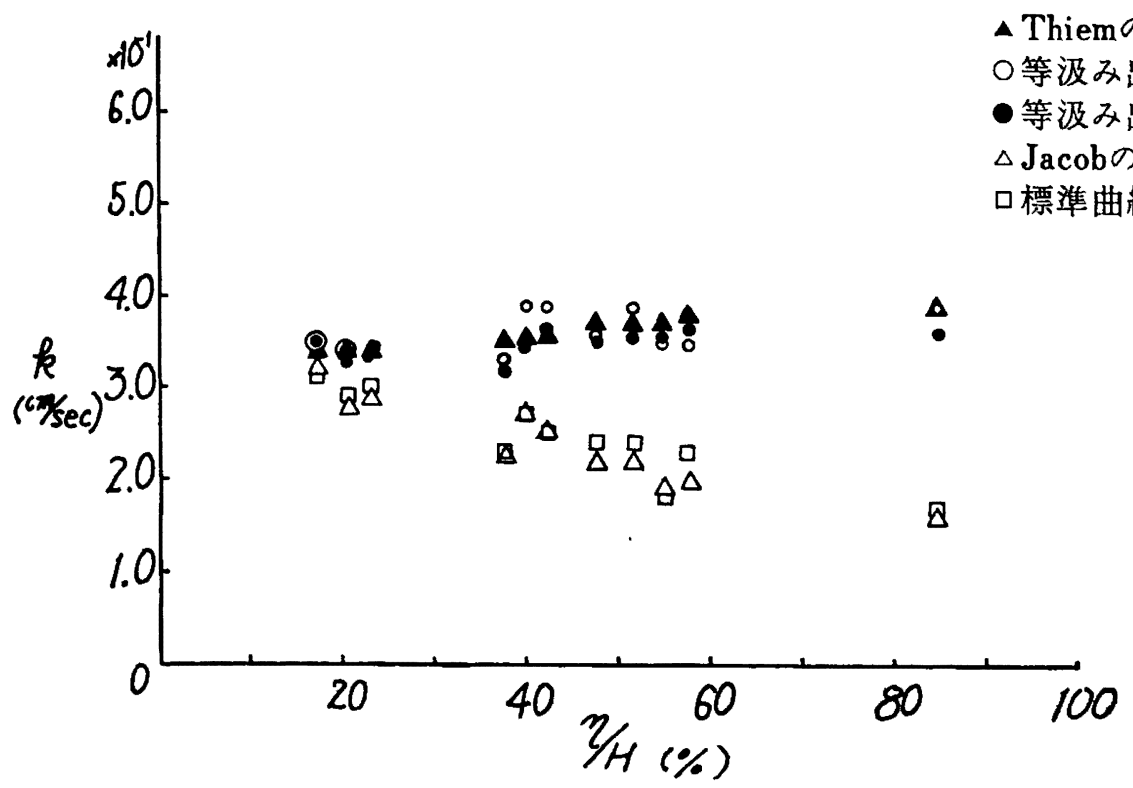

困 5-4 各解法による解析結果（室内実験） 
表わしたものである。

図 5-3を見ると，等汲み出し線法 (I)，標準曲線法，Jacob の直線法で，井戸から離れるにした がって，透水係数が大きくなっている。これは，3.でも述べたように，等汲み出し線法（I），揚水 井に対して表わされていることが原因となっているように思われる。次に図 5-4で, 透水係数の解 析值を見ると，標準曲線法と Jacobの直線法による值が，水位降下率が大きくなるにしたがって，小 さくなっている。これは，3.で述べたように，Theis・野満の解が，水位降下が初期水位に比べ十分 小さいとして解いていることが原因となっているものと思われる。また，有効空吵率は，等汲み出し 線法（I），（II)を除く他の方法では，水位降下率が大さくなるにしたがって，大きくなる。したがっ て, Theis・野満の解を基礎にしている標準曲線法や Jacob の直線法は, 図式解法といら方法の特性 る考慮に入れて，その適用限界は，水位降下率15２0\%付近と思われる。以上のように，等汲み出し 線法（I），標準曲線法，Jacob の直線法は，1本の実験曲線を解祈するのであるから，曲線のいたる ところで解祈可能であり，上記のよらな方法をとっても解祈值にある程度の幅がでてくる。これに対 して，等汲み出し線法（II )では，揚水井および各観測井のデータを同時に解祈できるので，比較的安 定した結果を得ることができるものと思われる。また，等汲み出し線法（II）では，揚水井の水位降下 が大きくなると, 観測井のデータはよく合致するが, 揚水井扰よび揚水井の近くの観測井のデータ は，計算曲線を下回る。そして，図 5-2を見るとわかるよらに，揚水開始直後では，計算曲線を上 回っている。これらは, 基礎式の井戸に打ける条件が不十分, 直接測定でないための Time-Lag 等 の原因が考えられる。

\section{6. 現場揚水試験データへの適用}

\section{$6-1$ 帯水層}

5.では, 室内実験を行ない, 等汲み出し線法 (I )，（II )について検討し，考察を行なってきたが， ここでは，さらに，現場のデータ 2 例について適用し，検討を加える。

2 例のデータの諸元は, データ $\mathrm{A}$ の場合, 揚水量 $\mathrm{Q}=260 \mathrm{~cm}^{3} / \mathrm{sec}$, 初期水位 $13.3 \mathrm{~m}$, 観測井は, 揚水井の中心から $3 \mathrm{~m}, 10 \mathrm{~m}, 20 \mathrm{~m}$ それぞれ離れた 3 本である。揚水井は，貫入率 $65 \%$ と不完全貫入井 である。な技，このデータは，赤井・宇野の論文より引用したものである。データ Bの場合，揚水量 $\mathrm{Q}=17667 \mathrm{~cm}^{3} / \mathrm{sec}$ ，初期水位 $579 \mathrm{~cm}$ ，観測井は，揚水井の中心からそれぞれ， $8.9 \mathrm{~m}, 11.95 \mathrm{~m}$, 23.15m離れた本である。揚水井の貫入率は，69\%である。

\section{6-2 解祈結果拈よび考察}

解祈は，両データとも，標準曲線法，Jacob の直線法，等汲み出し線法（Ｉ），（II）, Thiem の定 常解の各方法について行なった。この結果を表わしたのが表 6-1である。表 6-1では, 揚水井が 不完全貫入井であるから，M. Muskat の修正係数を乗じてある。

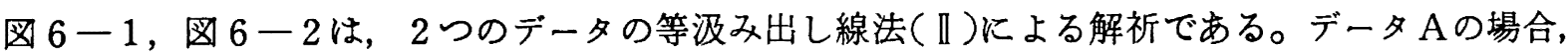
各観測井の曲線とも良く合致する。このデータで, 揚水開始後 1 日経過したときの影響半径と各観測 井の水位を予測してみると，1 日後の $\mathrm{y}_{0}$ の值は， $\mathrm{y}_{0}=4.66 \times 10^{-4}$ となり，このときの水位の時間的 空間的変化図上り，影響半径は， $\mathrm{R} \fallingdotseq 130 \mathrm{~m}$ ，揚水井の水位降下は， $105 \mathrm{~cm}$ ，各観測井の水位降下は， それぞれ，55cm，37cm，27cm となる。データBの場合，図6-2を見ればわかるよらに，揚水井 のデータを合致させると，各観測井のデータが，等汲み出し線( II)を下回っている。このことから， 帯水層が均質等方でなく，揚水井と観測井の位置の地質が異なることが想像される。 
表 6-1 帯水層定数解析表（現場揚水試験）

\begin{tabular}{|c|c|c|c|c|c|c|c|c|c|}
\hline & $\begin{array}{l}\text { 国測 } \\
\text { 井户 }\end{array}$ & 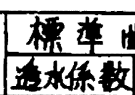 & 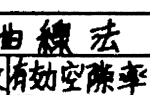 & $\frac{J a c o b n}{1}$ & 2直緗法 & 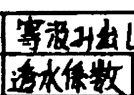 & 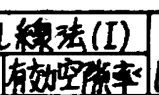 & 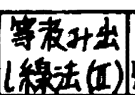 & 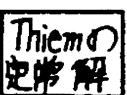 \\
\hline \multirow{3}{*}{ 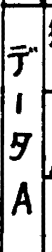 } & 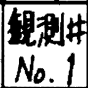 & $1.8 \times 10^{-3}$ & $6.3 \times 10^{-4}$ & $2.0 \times 10^{-3}$ & $4.1 \times 10^{-4}$ & $2.5 \times 10^{-3}$ & $6.6 \times 10^{-4}$ & \multirow{3}{*}{ 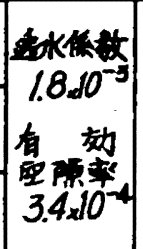 } & \multirow{3}{*}{$1.8 .10^{-3}$} \\
\hline & & $1.9 \times 10^{-3}$ & $5.7 \times 10^{-4}$ & $1.9 \times 10^{-3}$ & $6.2 \times 10^{-4}$ & $2.0 \times 10^{-3}$ & $5.6 \times 10^{-4}$ & & \\
\hline & & $2.1 \times 10^{-3}$ & $4.9 \times 10^{-4}$ & $2.1 \times 10^{-3}$ & $5.6 \times 10^{-4}$ & $2.0 \times 10^{-5}$ & $73 \times 10^{-4}$ & & \\
\hline & 揭水井 & $2.0 \times 10^{-1}$ & $5.9 \times 10^{-2}$ & $1.9 \times 10^{-1}$ & $7.2 \times 10^{-2}$ & $2.1 \times 10^{-1}$ & $7.2 \times 10^{-2} \mid$ & \multirow{4}{*}{$\begin{array}{l}\text { 適 } \\
\text { 用 } \\
\text { 瓜 } \\
\text { 能 }\end{array}$} & \multirow{4}{*}{$\begin{array}{l}\text { 一 } \\
\text { 定 } \\
\text { せ } \\
\text { お゙ }\end{array}$} \\
\hline & 钼則执 & $2.3 \times 10^{\prime}$ & $7.4 \times 10^{-3}$ & $2.2 \times 10^{-1}$ & $7.8 \times 10^{-3}$ & $2.2 \times 10^{-1}$ & $1.2 \times 10^{-2}$ & & \\
\hline \multirow[t]{2}{*}{$B$} & $\mathrm{Na}, 6$ & $2.3 \times 10^{-1}$ & $4.8 \times 10^{-3}$ & $2.3 \times 10^{-1}$ & $4.9 \times 10^{-3} \mid$ & $2.2 \times 10^{-1}$ & $7.3 \times 10^{-3} \mid$ & & \\
\hline & No.7 & $2.4 \times 70$ & & & & $2.4 \times 10$ & $3.1 \times 10^{-3}$ & & \\
\hline
\end{tabular}

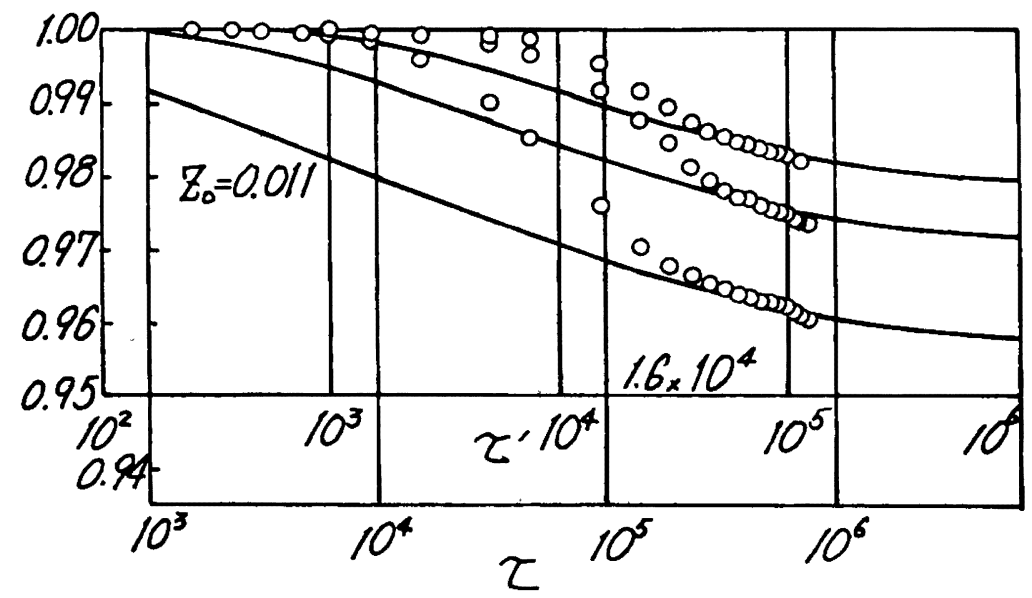

図 6-1 等汲み出し線法(II)適用図(データA)

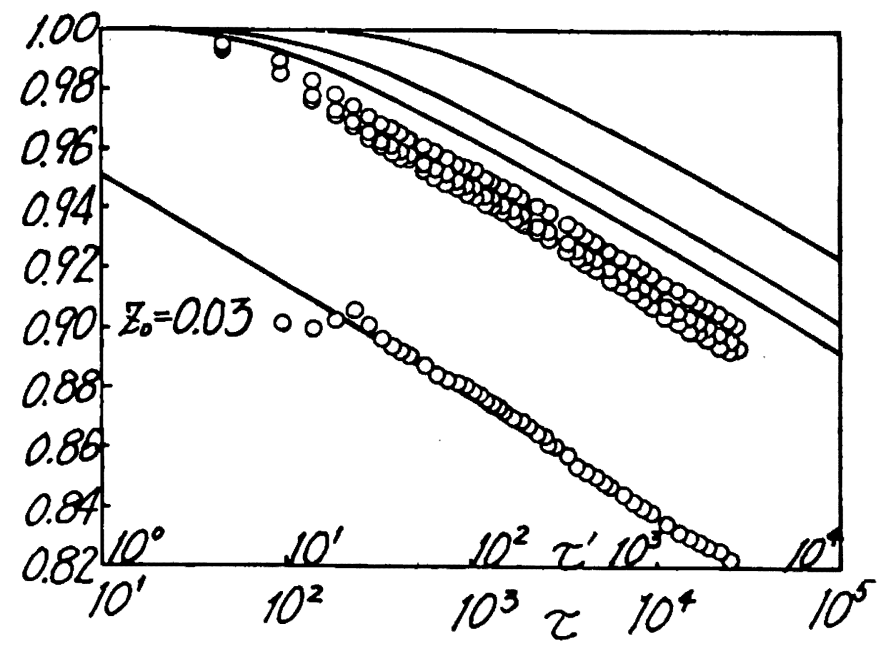

図 6-2 等汲み出し線法(II)適用図(データB) 


\section{7. 結 論}

以上, 従来の研究特よび各解法と等汲み出し線法を理論的な面と実験的な面で検討を行なってき た。その結果次のような結論を得た。

1）等汲み出し線図 (非線形解) と Theis・野満の解（線形解）を比較すると，水位降下が初期水 位の $10 \%$ 程度まで一致する。

2）従来, 無限に広がる帯水層に対し, 井戸の半径が微少であるとして, 井戸の半径を無視して解 いて来たが，井戸の半径を有限として解いた等汲み出し線を用いれば，観測井についても揚水井 における解祈值や定常解とほぼ等しい值が得られた。

3）等汲み出し線法（II）では，何本かの実験曲線を同時に適用するので，解析位置の決定に手間が 省け，また，より安定した帯水層定数を算定でさる。

4）井戸の半径を有限として解を求めた非線形解（等汲み出し線（II））を用いれば，任意時刻にお ける影響半径や任意地点の水位降下も簡単に予測できる。

5）等汲み出し線法の適用限界については，室内実験では，水位降下率50\%付近でも水位降下率20 \%付近の值とそれほど差がなかったが，鉛直流の考虑をしていないため，この鉛直流を考虑した 場合と比較して，決定する必要があろう。

今後は，井戸に和ける条件，井戸ロスの評価，Darcy の法則，鉛直流の考虑，不飽和の問題，異 方性，不均質，漏水がある場合等の諸問題に関して検討を行なら必要があるう。

\section{参 考 献}

1) Theis, C.V. (1935): The relation between the lowering of the piezometric surface and the rate and duration of discharge of a well using ground-water storage, Trans. Amer. Geophys. Union, Reports and papers, Hydrology, pp. 519 524.

2）野满隆治・山下 㢣 (1945)：井戸理論の一進展 (第 2 報), 地球物理, 7 巻 1 号, pp $21 \sim 40$.

3) 岸力 (1968): 水理学演習 (1), 学献社, pp. 274 278.

4) Cooper, C.C., Jr. and Jacob, C.E. (1946): A generalized graphical method for evaluating formation constnls and summarizing well-field history, Trans. Amer. Geophys. Union, papers, Hydrology, Vol. 27, No. 4, pp. 526 534.

5）三宅康夫, 岸 力 (1966) : 井戸への非定常地下水流に対する非線形解, 第21回年次学術講演会講演集, 土木学会, pp. 94-1 94-2.

6）三宅康夫（1967）：現塄揚水試験の非線形解, 土と基礎, No. 515, October, pp. 19２4.

7) Kriz, GJ., Scott, V.H. and Burgy, R. H. (1966): Analysis of parameters of an unconfined aquifer, Jour. Hydraulic Division, Proc. ASCE. Vol. 92, HY5, Proc. paper 4901, September, pp. $49 \sim 56$.

8) Kriz, G. J. (1967): Ditermination of unconfined aquifer characteristics, Jornal of the Irrigation and Dranage Division, ASCE., Vol. 93, No. IR2, Proc. paper 5269, June, 37 47.

9）星田義治・浜野啓造・市川 勉（1976）：带水層定数算定のための非定常解析に括ける2，3の問題，第11 回土質工学研究発表会講演集, 土質工学会, pp. 749 752.

10）星田義治・浜野啓造・市川 勉（1976）：揚水とよる非定常状態の数値解( II)，昭和51年度秋季講演会講演 集, 日本地下水学会, pp. 22 23.

11）星田義治・浜野啓造・市川 勉（1975）：不王地下水の揚水による帯水層定数の算定法（第 2 報），東海大 
学紀要工学部, 1975-2, pp. 73〜93.

12）星田義治・浜野啓造・市川 勉（1975）：帯水層定数の算定法に関する一実験, 第30回年次学術講会講演集 一II，土木学会, pp. 230 231.

13）星田義治・浜野啓造・飯田邦彦（1974）：不王地下水の揚水による帯水層定数の算定法（第 1 報），東海大 学紀要工学部, $1974-2$ pp. 55 62.

14）赤井浩一・宇野尚雄(1964)：自由水面をもつ地下水の揚水試験に対する考察, 土と基礎, Vol. 12, No, 7, July, pp. $15 \sim 19$.

15) Muskat, M., (1937): The flow of homogeneous fluid through porous media, Mc GRaw-Hill,. pp. 96.

（受付：1977年 3 月31日, 受理 : 1977年 7 月 2 日） 